\title{
PERBEDAAN TINGKAT PENGETAHUAN DAN SIKAP TENTANG HIV/AIDS PADA WARIA PEKERJA SEKS KOMERSIAL DAN WARIA NON-PEKERJA SEKS KOMERSIAL DI KOTA MANADO
}

\author{
Laila Awad \\ Christofel Elim \\ Anita E. Dundu \\ Neni Ekawardani \\ ${ }^{1}$ Kandidat Skripsi Fakultas Kedokteran Universitas Sam Ratulangi Manado \\ ${ }^{2}$ Bagian Psikiatri Fakultas Kedokteran Universitas Sam Ratulangi Manado \\ Email: laila.awad@ymail.com
}

\begin{abstract}
HIV/AIDS is a health problem that is threatening the world, including Indonesia. Manado has a high prevalence of HIV/AIDS in North Sulawesi with numbers of cases of 101 patients with HIV and 212 patients with AIDS in 2011. According to the group transmission, transvestites belong to the second rank of high risk group spreaders of HIV/AIDS due to the transvestites sex life impact. This was an observational analytical study with a cross sectional design. Samples were obtained by using the purposive sampling technique. We used questionnaire to be filled by 60 transvestites and a qualitative study on 2 transvestites to obtain more accurate data. The collected data were analyzed by using SPSS 20.0. The Mann-Whitney statistical test showed that there was a significant difference of knowledge between Transvestites Commercial Sex Workers and Transvestites Non-Commercial Sex Workers (p $<0.05)$. The significant value was due to the difference of attitudes between Transvestite Commercial Sex Workers and Transvestite Non-Commercial Sex Workers $(p<0.05)$.
\end{abstract}

Keywords: knowledge, attitude, HIV/AIDS, transvestite commercial sex worker, transvestite non-commercial sex worker

\begin{abstract}
Abstrak: HIV/AIDS merupakan masalah kesehatan yang masih mengancam dunia termasuk Indonesia hingga saat ini. Manado merupakan kota dengan prevalensi HIV/AIDS tertinggi di Sulawesi Utara dengan jumlah kasus 101 pasien HIV dan 212 pasien AIDS pada tahun 2011. Menurut kelompok penularannya, waria menduduki urutan kedua sebagai kelompok resiko tinggi penyebar HIV/AIDS akibat dari dampak kehidupan seks kaum waria. Penelitian ini besifat analitik observasional dengan pendekatan Cross-Sectional dengan teknik pengambilan sampel yaitu Purposive Sampling. Penelitian ini dilakukan dengan menggunakan kuisioner kepada 60 waria dan dilanjutkan dengan penelitian kualitatif terhadap 2 orang waria untuk memperoleh data yang lebih akurat. Data yang diperoleh diolah dengan SPSS 20.0. Hasil pengolahan data menggunakan analisis statistik Mann-Whitney menunjukkan nilai signifikan adanya perberdaan tingkat pengetahuan antara Waria PSK dan Waria Non-PSK $(p<0,05)$. Nilai yang signifikan diperoleh dengan adanya perbedaan sikap antara Waria PSK dan Waria Non-PSK $(\mathrm{p}<0,05)$.
\end{abstract}

Kata kunci: pengetahuan, sikap, HIV/AIDS, waria PSK, waria non-PSK 
Acquired Immunodeficiency Syndrome (AIDS) merupakan penyakit menular yang disebabkan oleh Human Immunodeficiency Virus (HIV). HIV/AIDS merupakan masalah besar yang mengancam negara didunia termasuk Indonesia. United Nations Programme on HIV/AIDS (UNAIDS), yaitu badan World Helath Organization (WHO) yang menangani masalah AIDS memperkirakan jumlah orang dengan HIV/AIDS (odha) diseluruh dunia pada Desember 2004 adalah 35,9 44,3 juta orang. ${ }^{1}$

Berdasarkan data South East Asia Regional Office (SEARO) pada tahun 2011, India, Indonesia, Myanmar, Nepal dan Thailand merupakan negara dengan penyebaran HIV/AIDS terbesar. India merupakan negara diurutan pertama penyebaran HIV/AIDS dimana 2,4 juta penduduk India menderita HIV/AIDS. Indonesia berada di urutan ke-4 dengan jumlah penderita HIV/AIDS sebanyak 190.000 jiwa. $^{2}$

Bidang Pengendalian Masalah Kesehatan Dinas Kesehatan (PMK Dinkes) Sulut mencatat, jumlah kasus HIV/AIDS pada tahun 2011 sebanyak 878 kasus. Manado merupakan kota dengan prevalensi tertinggi di Sulut dengan jumlah kasus HIV/AIDS yaitu 313 orang,yang terdiri dari 101 pasien HIV dan 212 pasien AIDS pada tahun 2011. Prevalensi HIV/AIDS menurut kelompok penularannya, sebesar 42,4\% HIV/AIDS diderita oleh pengguna narkoba suntik (penasun), Waria 23,2\%, Wanita Penjaja Seks (WPS) langsung 9,3\%, WPS tidak langsung 3,1\% dan lainlain $0,7 \%$. Angka tersebut menunjukan bahwa salah satu kelompok resiko tinggi penyebar HIV/AIDS yang keberadaannya saat ini cukup mengkhawatirkan karena aktivitas yang melekat dalam keseharian mereka adalah kelompok waria. ${ }^{5,3}$ Dalam berusaha memenuhi kebutuhan hidupnya, terdapat waria yang bekerja sebagai pekerja seks komersial dan ada juga waria yang bekerja dengan mengembangkan keahliannya dibidang salon, perancang busana, dan penata rias. Komunitas waria termasuk kelompok resiko tinggi penyebar
HIV/AIDS terutama waria yang bekerja sebagai PSK dengan berganti-ganti pasangan. Selain itu perilaku seks waria yang melakukan hubungan seks dengan penetrasi ke dalam anus (anal seks) serta melakukan aktivitas oral seks pada pasangannya merupakan perilaku berisiko karena kemungkinan terjadinya luka sehingga memudahkan terjadinya penularan HIV/AIDS. Rendahnya pengetahuan tentang penularan dan pencegahan, serta rentannya gaya hidup seksual waria terhadap HIV/AIDS mengakibatkan prevalensi IMS dan HIV/AIDS masih cukup tinggi dikalangan waria. $^{3}$

\section{METODE PENELITIAN}

Penelitian ini bersifat analitik observasional dengan pendekatan CrossSectional dengan teknik pengambilan sampel yaitu Purposive Sampling. Penelitian ini dilakukan dengan menggunakan alat ukur berupa kuisioner kepada 60 waria dan dilanjutkan dengan penelitian kualitatif terhadap 2 orang waria untuk memperoleh data yang lebih akurat. Data yang sudah diperoleh kemudian diolah dengan menggunakan SPSS 20.0.

\section{HASIL PENELITIAN DAN BAHASAN}

Jumlah responden yang berpartisipasi dalam penelitian mengenai perbedaan tingkat pengetahuan dan sikap tentang HIV/AIDS pada waria Pekerja Seks Komersial (PSK) dan waria Non-Pekerja Seks Komersial (Non-PSK) di kota Manado yaitu sebanyak 60 responden, dimana 30 responden merupakan Waria PSK dan 30 responden merupakan Waria Non-PSK.

\section{Analisis Univariat Usia}

Tabel 1 menunjukkan bahwa sebagian besar usia responden berada pada golongan 10-20 tahun dan 21-30 tahun dengan jumlah masing-masing 20 responden (33,3\%), sedangkan yang paling sedikit pada golongan usia $>50$ tahun dengan jumlah 1 responden (1,7\%). 
Tabel 1. Distribusi Frekuensi Berdasarkan Usia Responden

\begin{tabular}{ccccc}
\hline $\begin{array}{c}\text { Golongan } \\
\text { Usia }\end{array}$ & PSK & $\begin{array}{c}\text { Non- } \\
\text { PSK }\end{array}$ & N & $\%$ \\
\hline $10-20$ thn & 19 & 1 & 20 & 33,3 \\
$2-30$ thn & 11 & 9 & 20 & 33,3 \\
$31-40$ thn & 0 & 8 & 8 & 13,3 \\
$41-50$ thn & 0 & 11 & 11 & 18,3 \\
$>50$ thn & 0 & 1 & 1 & 1,7 \\
\hline Total & 30 & 30 & 60 & 100 \\
\hline
\end{tabular}

Hal ini hampir sama dengan penelitian yang dilakukan oleh Rahmayani $\mathrm{V}$ et al. pada 40 responden waria di Kota Padang pada bulan Mei 2013 dimana tidak terdapat responden yang tergolong dalam ketegori usia $>70$ tahun. $^{2}$

\section{Pendidikan terakhir}

Tabel 2 menunjukkan bahwa sebagian besar tingkat pendidikan dari 60 responden waria yaitu SMP/sederajat dengan jumlah 23 responden (38,3\%), sedangkan yang paling sedikit ialah jumlah waria yang tidak pernah sekolah dengan jumlah 3 responden (5\%). Hal ini menunjukkan bahwa sebagian besar waria telah mengikuti jenjang pendidikan formal wajib belajar 9 tahun sehingga dapat memengaruhi tingkat pengetahuan waria.

Tabel 2. Distribusi Frekuensi Berdasarkan Pendidikan Responden

\begin{tabular}{ccccc}
\hline Pendidikan & PSK & $\begin{array}{c}\text { Non- } \\
\text { PSK }\end{array}$ & N & $\%$ \\
\hline Tidak Sekolah & 3 & 0 & 3 & 5,0 \\
SD/Sederajat & 13 & 1 & 14 & 23,3 \\
SMP/Sederajat & 8 & 15 & 23 & 38,3 \\
SMA/Sederajat & 5 & 10 & 15 & 25,0 \\
Akademi/PT & 1 & 4 & 5 & 8,3 \\
\hline Total & 30 & 30 & 60 & 100 \\
\hline
\end{tabular}

\section{Status tinggal dengan pasangan tetap}

Tabel 3 menunjukkan bahwa sebagian besar responden tidak tinggal bersamasama dengan pasangan tetapnya dengan jumlah 57 responden (95\%), dan yang lainnya tinggal dengan pasangan tetapnya hanya 3 responden (5\%).
Tabel 3. Distribusi Frekuensi Berdasarkan Status Tinggal Dengan Pasangan Tetap

\begin{tabular}{ccc}
\hline Status Tinggal & $\mathrm{N}$ & $\%$ \\
\hline Ya & 3 & 5,0 \\
Tidak & 57 & 95,0 \\
\hline Total & 60 & 100 \\
\hline
\end{tabular}

\section{Status tinggal dengan keluarga}

Tabel 4 menunjukkan bahwa responden yang tidak tinggal bersama-sama dengan keluarganya dengan jumlah 42 responden (70\%), dan yang lainnya tinggal dengan keluarganya dengan jumlah 18 responden (30\%). Hal ini membuktikan sebagian besar responden didapatkan merasa lebih leluasa untuk hidup tanpa adanya tekanan dari keluarga maupun orang lain agar dapat mengekspresikan diri sebagai individu yang mengalami transisi gender. Hal ini cukup membuktikan teori yang disampaikan oleh Beemyn $G$ dan Rankin $S$ dalam bukunya yang berjudul The Lives of Transgender People yang mengatakan bahwa adanya pengaruh pemahaman yang dimiliki orang dengan transisi gender yang terjadi pada usia yang relatif dini, sebagai remaja atau bahkan sebagai anak-anak memungkinkan mereka mencoba memahami perasaan internal tentang adanya perbedaan yang tejadi pada diri masing-masing tanpa ingin merasa kebingungan, ada penyembunyian, atau malu untuk menjadi diri sendiri tanpa adanya tekanan dari pihak lain. ${ }^{4}$

Tabel 4. Distribusi Frekuensi Berdasarkan Status Tinggal dengan Keluarga

\begin{tabular}{ccc}
\hline Status Tinggal & $\mathrm{N}$ & $\%$ \\
\hline Ya & 18 & 30,0 \\
Tidak & 42 & 70,0 \\
\hline Total & 60 & 100 \\
\hline
\end{tabular}

\section{Profesi}

Berdasarkan Tabel 5 dapat dilihat bahwa responden dengan profesi sebagai PSK berjumlah 30 responden (50\%), dan responden yang berprofesi sebagai NonPSK berjumlah 30 responden (50\%). 
Tabel 5. Distribusi Frekuensi Berdasarkan Profesi Responden

\begin{tabular}{ccc}
\hline Profesi & N & $\%$ \\
\hline PSK & 30 & 50,0 \\
Non PSK & 30 & 50,0 \\
\hline Total & 60 & 100 \\
\hline
\end{tabular}

\section{Pekerjaan Sampingan}

Berdasarkan Tabel 6 dapat dilihat bahwa pekerjaan sampingan responden dari profesi masing-masing waria menunjukan bahwa responden yang bekerja sebagai pekerja salon dengan jumlah 25 responden (41,7\%).

Tabel 6. Distribusi Frekuensi Berdasarkan Pekerjaan Sampingan Responden

\begin{tabular}{ccc}
\hline Pekerjaan & $\mathrm{N}$ & $\%$ \\
\hline Mahasiswa & 1 & 1,7 \\
Kerja di Salon & 25 & 41,7 \\
Singer & 5 & 8,3 \\
Wiraswasta & 11 & 18,3 \\
Tidak Ada & 18 & 20 \\
Total & 60 & 100 \\
\hline
\end{tabular}

\section{Pengetahuan dan sikap}

Wiraswasta dengan jumlah 11 responden (18,3\%), Mahasiswa dengan jumlah 1 responden (1,7\%) dan yang tidak memiliki pekerjaan atau murni sebagai PSK berjumlah 18 responden (20\%). \%). Berbeda dengan penelitian yang dilakukan oleh Widjanarko et al. dimana hasil penelitian pada pekerjaan responden cukup tinggi sebagai tukang salon (83.0\%) dan hanya (3.0\%) responden yang tidak memiliki pekerjaan. ${ }^{5}$

Pada penelitian ini ditemukan perbedaan yang cukup signifikan terhadap hasil penelitian tingkat pengetahuan dan sikap responden terhadap HIV/AIDS dimana sebagian besar responden sudah mempunyai pengetahuan yang baik dengan jumlah 30 responden (50\%), pengetahuan cukup dengan jumlah 27 responden (45\%) dan pengetahuan kurang berjumlah 3 responden (5\%) (Tabel 7).

Berdasarkan tingkat pengetahuan tersebut responden yang sudah memiliki sikap yang positif terhadap HIV/AIDS dengan jumlah 32 responden (53,3\%), dan yang memiliki sikap negatif terhadap HIV/AIDS dengan jumlah 28 responden (46,7\%) (Tabel 8). Hasil penelitian ini didapatkan dengan menggunakan skala penelitian Guttman untuk tingkat pengetahuan dan skala penelitian Likert untuk sikap.

Tabel 7. Distribusi Frekuensi Berdasarkan Tingkat Pengetahuan Responden

\begin{tabular}{ccc}
\hline Tingkat Pengetahuan & N & $\%$ \\
\hline Baik & 30 & 50,0 \\
Cukup & 27 & 45,0 \\
Kurang & 3 & 5,0 \\
\hline Total & 60 & 100 \\
\hline
\end{tabular}

Tabel 8. Distribusi Frekuensi Berdasarkan Sikap Responden

\begin{tabular}{ccc}
\hline Sikap & N & $\%$ \\
\hline Positif & 32 & 53,3 \\
Negatif & 28 & 46,7 \\
\hline Total & 60 & 100 \\
\hline
\end{tabular}

Skala Guttman dapat dibuat dalam bentuk pilihan ganda maupun daftar checklist, yaitu skala yang menginginkan tipe jawaban tegas, seperti jawaban benar salah, ya - tidak, dan seterusnya sedangkan skala Likert adalah skala yang dapat dipergunakan untuk mengukur sikap, pendapat, dan persepsi seseorang mengenai suatu gejala atau fenomena. Dalam skala Likert terdapat dua bentuk pernyataan yaitu pernyataan positif yang berfungsi untuk mengukur sikap positif, dan pernyataan negatif yang berfungsi untuk mengukur sikap negatif objek sikap. ${ }^{6}$

\section{Analisis Bivariat}

\section{Analisis Cross Tabulation Pendidikan dengan Pengetahuan}

Berdasarkan hasil analisis dengan tabulasi silang responden dengan pendidikan jenjang perguruan tinggi dari total 5 responden yang berpartisipasi didapatkan 4 responden (805) yang berpengetahuan baik sedangkan 1 
responden (20\%) masih berpengetahuan cukup.

Hal ini memperlihatkan bahwa waria yang sampai pada bangku kuliah sudah memiliki wawasan yang baik khususnya tentang apa itu HIV/AIDS, bagaimana penularannya dan bagaimana pencegahannya. kemudian terlihat juga responden dengan pendidikan SMA/sederajat yang mempunyai pengetahuan baik sebanyak 10 responden $(66,7 \%)$ sedangkan pada responden dengan pendidikan SMP/sederajat sudah mempunyai pengetahuan baik tentang HIV/AIDS dengan jumlah 15 responden (65,2\%), ada pula responden dengan pendidikan
SD/sederajat sebagian besar mempunyai pengetahuan yang cukup dengan jumlah 12 responden (85,7\%), tetapi perbedaan pengetahuan waria terlihat pada responden yang tidak pernah sekolah diamana kebanyakan mempunyai pengetahuan yang masih kurang dengan jumlah 2 responden $(66,7 \%)$ dari total 3 responden yang tidak sekolah. Hal ini sejalan dengan penelitian Rahmayani V,dkk pada tahun 2013 di Kota Padang dimana lebih dari separuh responden yaitu sebanyak $70 \%$ memiliki tingkat pengetahuan yang baik terhadap HIV-AIDS dengan jumlah responden sebanyak 28 waria. $^{2}$

Tabel 9. Analisis Cross Tabulation Pendidikan dengan Pengetahuan

\begin{tabular}{|c|c|c|c|c|c|c|c|c|c|}
\hline \multirow{3}{*}{\multicolumn{2}{|c|}{ Variabel Penelitian }} & \multicolumn{7}{|c|}{ Pengetahuan } & \multirow{3}{*}{$\begin{array}{c}\text { Total } \\
\%\end{array}$} \\
\hline & & \multicolumn{2}{|c|}{ Baik } & \multicolumn{2}{|c|}{ Cukup } & \multicolumn{3}{|c|}{ Kurang } & \\
\hline & & $\mathrm{n}$ & $\%$ & $\mathrm{n}$ & $\%$ & $\mathrm{n}$ & $\%$ & $\mathrm{~N}$ & \\
\hline \multirow{5}{*}{ Pendidikan } & Tidak Sekolah & 0 & 0 & 1 & 33,3 & 2 & 66,7 & 3 & 100 \\
\hline & SD/Sederajat & 1 & 7,1 & 12 & 85,7 & 1 & 7,1 & 14 & 100 \\
\hline & SMP/Sederajat & 15 & 65,2 & 8 & 34,7 & 0 & 0 & 23 & 100 \\
\hline & SMA/Sederajat & 10 & 66,7 & 5 & 33,3 & 0 & 0 & 15 & 100 \\
\hline & Akademi/PT & 4 & 80 & 1 & 20 & 0 & 0 & 5 & 100 \\
\hline
\end{tabular}

Penelitian ini juga memperkuat teori yang dikemukakan oleh Notoatmodjo bahwa tingkat pendidikan seseorang dapat meningkatkan pengetahuan khususnya pengetahuan di bidang kesehatan. Semakin tinggi tingkat pendidikan seseorang semakin mudah menyerap informasi termasuk juga informasi kesehatan sehingga mereka tahu bagaimana cara pencegahan dan penularan penyakit HIVAIDS.

Tingkat pendidikan yang dimiliki mulai dari jenjang sekolah dasar hingga jenjang perguruan tinggi juga mempengaruhi sikap yang akan dipilih responden. Seseorang akan mampu mengambil tindakan atau menanggapi suatu masalah dengan pengaruh wawasan yang dimiliki. hasil dalam penelitian ini menunjukan bahwa responden yang tidak sekolah seluruhnya bersikap negatif terhadap HIV/AIDS. Namun juga terlihat dari hasil bahwa waria yang sudah mencapai pendidikan hingga SMP/sederajat maupun SMA/sederajat sebagian besar sudah mampu bersikap positif terhadap HIV/AIDS. Selain itu total 5 responden waria dengan pendidikan perguruan tinggi seluruhnya bersikap positif yaitu sebanyak 5 responden (100\%). Hal ini membuktikan bahwa pentingnya pendidikan formal diseluruh kalangan termasuk kalangan waria karena dapat mempengaruhi bagaimana pola pikir khususnya yang melibatkan kesehatan. Penelitian ini hampir sama dengan penelitian yang dilakuan oleh Herdiyanto $\mathrm{P}$ mempunyai sikap yang positif terhadap HIV/AIDS. ${ }^{9}$ 


\section{Analisis Cross Tabulation Pendidikan dengan Sikap}

Tabel 10. Analisis Cross Tabulation Pendidikan dengan Sikap

\begin{tabular}{|c|c|c|c|c|c|c|c|}
\hline \multirow{2}{*}{\multicolumn{2}{|c|}{ Variabel Penelitian }} & \multicolumn{4}{|c|}{ Sikap } & \multirow{2}{*}{\multicolumn{2}{|c|}{ Total }} \\
\hline & & \multicolumn{2}{|c|}{ Positif } & \multicolumn{2}{|c|}{ Negatif } & & \\
\hline & & $\mathrm{N}$ & $\%$ & $\mathrm{n}$ & $\%$ & $\mathrm{~N}$ & $\%$ \\
\hline \multirow{5}{*}{ Pendidikan } & Tidak Sekolah & 0 & 0 & 3 & 100 & 3 & 100 \\
\hline & SD/Sederajat & 2 & 14,2 & 12 & 85,7 & 14 & 100 \\
\hline & $\begin{array}{c}\text { SMP/Sederaja } \\
\mathrm{t}\end{array}$ & 14 & 60,8 & 9 & 39,1 & 23 & 100 \\
\hline & $\begin{array}{c}\text { SMA/Sederaj } \\
\text { at }\end{array}$ & 11 & 73,3 & 4 & 26,7 & 15 & 100 \\
\hline & Akademi/PT & 5 & 100 & 0 & 0 & 5 & 100 \\
\hline
\end{tabular}

\section{Analisis Cross Tabulation Profesi dengan Pengetahuan}

Tabel 11. Analisis Cross Tabulation Profesi dengan Pengetahuan

\begin{tabular}{|c|c|c|c|c|c|c|c|c|c|}
\hline \multirow{2}{*}{\multicolumn{2}{|c|}{ Variabel Penelitian }} & \multicolumn{6}{|c|}{ Pengetahuan } & \multirow{2}{*}{\multicolumn{2}{|c|}{ Total }} \\
\hline & & \multicolumn{2}{|c|}{ Baik } & \multicolumn{2}{|c|}{ Cukup } & \multicolumn{2}{|c|}{ Kurang } & & \\
\hline & & $\mathrm{n}$ & $\%$ & $\mathrm{n}$ & $\%$ & $\mathrm{n}$ & $\%$ & $\mathrm{~N}$ & $\%$ \\
\hline \multirow{2}{*}{ Profesi } & PSK & 0 & 0 & 27 & 90 & 3 & 10 & 30 & 100 \\
\hline & Non- PSK & 30 & 100 & 0 & 0 & 0 & 0 & 30 & 100 \\
\hline
\end{tabular}

Berdasarkan hasil penelitian didapatkan bahwa 30 responden Waria Non-PSK (100\%) sudah mempunyai pengetahuan yang baik tentang HIV/AIDS, sedangkan pada responden Waria PSK yang mempunyai pengetahuan cukup sebanyak 27 responden (90\%) dan pengetahuan kurang sebanyak 3 responden (10\%). Hal ini sejalan dengan penelitian Rahmayani V,dkk di Kota Padang pada tahun 2013.
Hasil penelitian menunjukan bahwa pada umumnya waria sudah mengetahui pengertian dari HIV/AIDS (81\%), cara penularan HIV/AIDS (74\%), pencegahan penularan HIV/AIDS (86\%), pengertian, kegunaan, dan cara penggunaan (54\%, $86 \%$, dan $74 \%$ ), akibat tidak menggunakan kondom (88\%), dan kelompok yang beresiko tertular HIV/AIDS (61\%). ${ }^{2}$

\section{Analisis Cross Tabulation Profesi dengan Sikap}

Tabel 12. Analisis Cross Tabulation Profesi dengan Sikap

\begin{tabular}{|c|c|c|c|c|c|c|c|}
\hline \multirow{2}{*}{\multicolumn{2}{|c|}{ Variabel Penelitian }} & \multicolumn{4}{|c|}{ Sikap } & \multirow{2}{*}{\multicolumn{2}{|c|}{ Total }} \\
\hline & & \multicolumn{2}{|c|}{ Positif } & \multicolumn{2}{|c|}{ Negatif } & & \\
\hline & & $\mathrm{N}$ & $\%$ & $\mathrm{~N}$ & $\%$ & $\mathrm{~N}$ & $\%$ \\
\hline \multirow[b]{2}{*}{ Profesi } & PSK & 6 & 20 & 24 & 80 & 30 & 100 \\
\hline & $\begin{array}{l}\text { Non } \\
\text { PSK }\end{array}$ & 26 & 86,7 & 4 & 13,3 & 30 & 100 \\
\hline
\end{tabular}


Profesi waria juga mempengaruhi sikap dan respon yang dipilih oleh waria. Hasil penelitian menunjukan bahwa Waria dengan profesi Non-PSK sebanyak 26 responden (81,25\%) sudah mempunyai sikap yang positif terhadap HIV/AIDS, sedangkan pada Waria dengan profesi PSK yang mempunyai sikap yang positif hanya sebanyak 6 responden (18,75\%).

Pada profesi PSK sebagian besar responden yaitu 24 responden (85,7\%) masih mempunyai sikap yang negatif terhadap HIV/AIDS, sedangkan pada profesi Non-PSK yang mempunyai sikap yang negatif adalah sebanyak 4 responden (14,2\%). Jika dibandingkan dengan penelitian yang dilakukan Rahmayani V,dkk pada waria di Kota Padang tahun 2013 didapatkan sebanyak 52,5\% responden memiliki sikap sedang terhadap pencegahan HIV/AIDS. Angka tersebut menunjukkan bahwa lebih dari separuh responden mempunyai sikap sedang dalam pencegahan penularan HIV/AIDS. ${ }^{2}$

\section{Analisis Cross Tabulation Pekerjaan Sampingan dengan Pengetahuan}

Tabel 13. Analisis Cross Tabulation Pekerjaan Sampingan dengan Pengetahuan

\begin{tabular}{|c|c|c|c|c|c|c|c|c|c|}
\hline \multirow{3}{*}{\multicolumn{2}{|c|}{ Variabel Penelitian }} & \multicolumn{6}{|c|}{ Pengetahuan } & \multirow{2}{*}{\multicolumn{2}{|c|}{ Total }} \\
\hline & & \multicolumn{2}{|c|}{ Baik } & \multicolumn{2}{|c|}{ Cukup } & \multicolumn{2}{|c|}{ Kurang } & & \\
\hline & & $\mathrm{n}$ & $\%$ & $\mathrm{~N}$ & $\%$ & $\mathrm{n}$ & $\%$ & $\mathrm{~N}$ & $\%$ \\
\hline \multirow{5}{*}{$\begin{array}{c}\text { Pek } \\
\text { erja } \\
\text { an }\end{array}$} & Mahasiswa & 0 & 0 & 1 & 100 & 0 & 0 & 1 & 100 \\
\hline & Salon & 19 & 76 & 6 & 24 & 0 & 0 & 25 & 100 \\
\hline & Singer & 0 & 0 & 5 & 100 & 0 & 0 & 5 & 100 \\
\hline & Wiraswasta & 11 & 100 & 0 & 0 & 0 & 0 & 11 & 100 \\
\hline & Tidak ada & 0 & 0 & 15 & 83,3 & 3 & 16,7 & 18 & 100 \\
\hline
\end{tabular}

Diluar profesinya, baik Waria PSK dan Waria Non-PSK memiliki pekerjaan sampingan untuk memenuhi kebutuhan hidupnya. Sesuai dengan pengetahuan yang dimiliki oleh masing-masing waria, suatu pekerjaan dapat diperoleh berdasarkan dengan bakat dan minatnya. Hasil penelitian menunjukan bahwa sebagian besar waria dengan pekerjaan sampingan sebagai pekerja salon sudah mempunyai pengetahuan yang baik tentang HIV/AIDS dengan jumlah 19 responden (76\%) dan dari seluruh waria dengan pekerjaan sampingan sebagai wiraswasta menunjukan pengetahuan yang baik dengan jumlah 11 responden $(100 \%)$ terutama pada waria Non-PSK. Sedangkan pada waria yang tidak memiliki pekerjaan sampingan sama sekali memiliki pengetahuan yang cukup dengan jumlah 15 responden (83,3\%) dan 3 responden $(16,7 \%)$ berpengetahuan kurang terutama pada waria PSK.

\section{Analisis Cross Tabulation Pekerjaan Sampingan dengan Sikap}

Tabel 14. Analisis Cross Tabulation Pekerjaan Sampingan dengan Sikap

\begin{tabular}{|c|c|c|c|c|c|c|c|}
\hline \multirow{2}{*}{\multicolumn{2}{|c|}{ Variabel Penelitian }} & \multicolumn{4}{|c|}{ Sikap } & \multirow{2}{*}{\multicolumn{2}{|c|}{ Total }} \\
\hline & & \multicolumn{2}{|c|}{ Positif } & \multicolumn{2}{|c|}{ Negatif } & & \\
\hline & & $\mathrm{N}$ & $\%$ & $\mathrm{~N}$ & $\%$ & $\mathrm{~N}$ & $\%$ \\
\hline \multirow{5}{*}{ Pekerjaan } & Mahasiswa & 1 & 100 & 0 & 0 & 1 & 100 \\
\hline & Salon & 17 & 68 & 8 & 32 & 25 & 100 \\
\hline & Singer & 1 & 20 & 4 & 80 & 5 & 100 \\
\hline & Wiraswasta & 11 & 100 & 0 & 0 & 11 & 100 \\
\hline & Tidak ada & 2 & 11,1 & 16 & 88,9 & 18 & 100 \\
\hline
\end{tabular}


Sikap atau respon terhadap HIV/AIDS berdasarkan pekerjaan sampingan masingmasing waria menunjukan hasil bahwa sebagian besar responden dengan pekerjaan sampingan sebagai pekerja salon sudah mempunyai sikap yang positif terhadap HIV/AIDS dengan jumlah 17 responden (68\%). Sedangkan dari 18 responden yang tidak ada pekerjaan mempunyai sikap yang negatif terhadap HIV/AIDS sebanyak 16 responden (88,9\%). Angka ini menunjukan perbedaan yang cukup signifikan terhadap tingkat pengetahuan dan sikap waria terhadap HIV/AIDS berdasarkan masingmasing pekerjaan waria.

Pada penelitian ini digunakan analisis statistik yaitu Mann-Whitney karena data tidak terdistribusi secara normal, dimana hasil analisis menunjukkan bahwa pada variabel pengetahuan menunjukkan nilai $Z_{\text {hitung }}=6,831$. Apabila dibandingkan dengan nilai $\mathrm{Z}_{\text {tabel }}$ pada dengan $\alpha=0,05$ diperoleh nilai $Z_{\text {tabel }}=1,635$, sehingga $Z_{\text {hitung }}=6,831>t_{\text {tabel }}=1,635$, dengan demikian hipotesis $\mathrm{H} 1$ diterima. Nilai signifikan juga menunjukkan $p=0,000$, apabila dibandingkan dengan $\alpha=5 \%$ $(0,05)$, maka nilai diperoleh $p=0,000<$ 0,05, dengan demikian hipotesis H1 diterima. Sedangkan pada pada variable sikap menunjukkan nilai $Z_{\text {hitung }}=6,219$. Apabila dibandingkan dengan nilai $Z_{\text {tabel }}$ pada dengan $\alpha=0,05$ diperoleh nilai $Z_{\text {tabel }}$ $=1,635$, sehingga $Z_{\text {hitung }}=6,219>t_{\text {tabel }}=$ 1,635, dengan demikian hipotesis $\mathrm{H} 1$ diterima. Nilai signifikan juga menunjukkan $p=0,000$, apabila dibandingkan dengan $\alpha=5 \%(0,05)$, maka nilai diperoleh $p=0,000<0,05$, dengan demikian hipotesis H1 diterima. Dengan melihat nilai $Z_{\text {hitung }}$ dan nilai $p$, maka disimpulkan bahwa terdapat perbedaan pengtahuan dan sikap terhadap HIV/AIDS pada waria PSK dan waria Non PSK di Kota Manado.

\section{SIMPULAN}

1. Waria Non-PSK sudah mempunyai pengetahuan yang baik tentang HIV/AIDS sedangkan Waria PSK sebagian besar masih mempunyai pengetahuan cukup tentang HIV/AIDS

2. Waria Non-PSK di Kota Manado sebagian besar sudah mempunyai sikap yang positif terhadap HIV/AIDS, sedangkan sebagian besar Waria PSK justru masih mempunyai sikap yang negatif.

3. Terdapat perbedaan tingkat pengetahuan dan sikap terhadap HIV/AIDS pada waria PSK dan waria Non PSK di Kota Manado

4. Diskriminasi yang sering dialami waria menyulitkan waria untuk berinteraksi dengan masyarakat sehingga waria cenderung memilih profesi sebagai PSK untuk dapat hidup sehari-hari dibandingkan harus mencari pekerjaan lain.

\section{SARAN}

1. Perlunya ditingkatkan kerja sama antara Dinas Kesehatan dan LSM di Kota Manado untuk lebih banyak melakukan program penyuluhan HIV/AIDS dengan sasaran waria.

2. Perlu adanya rasa kepedulian dan dukungan masyarakat agar waria merasa lebih diterima dan hidup dengan layak.

3. Perlu adanya kesadaran dalam setiap diri waria untuk mencari tahu informasi dan mengikuti penyuluhan HIV/AIDS di Kota Manado.

4. Perlunya diperbanyak penelitian mengenai tingkat pengetahuan waria beserta sikap waria tentang HIV/AIDS untuk menambah pengetahuan umum tentang waria.

5. Diharapkan penelitian selanjutnya dengan kasus serupa dapat dilakukan dengan metode yang berbeda akibat masih kurangnya penelitian tentang waria.

\section{DAFTAR PUSTAKA}

1. Djoerban Z, Djauzi S. Tropik Infeksi. Sudoyo AW, Setiyohadi B, Alqi I, Simadribata M, Setiati S. Buku Ajar Ilmu Penyakit Dalam Jilid III. Edisi V. Jakarta: Internal Publishing; 2009. 2861-64

2. Rahmayani V, Hanif AM, Sastri S. 
Hubungan Pengetahuan dan Sikap dengan Tindakan Pencegahan Penularan HIV-AIDS Pada Waria di Kota Padang Tahun 2013. Fakultas Kedokteran Universitas Andalas [diunduh 8 september 2014]. Available from: http://jurnal.fk.unand.ac.id

3. Cahyati Widya H. Gambaran Perilaku Seksual Waria Penderita Infeksi Menular Seksual dikota Semarang Tahun 2011 [Skripsi]. IKM FIK Universitas Negeri Semarang; 2011:4

4. Beemyn G, Rankin S. The Lives of Transgender People. New York: Columbia University Press Publishing; 2011. 33

5. Widjanarko B, Eda N, Widagdo L. Niat Penggunaan Kondom pada Komunitas Waria di Kota Ternate. Fakultas Keperawatan Universitas Diponegoro Semarang. Agustus 2012 [diunduh 1 januari 2015]. Available from

http://ejournal.undip.ac.id/index.php/j pki/article/download/5562/4944
6. Besral-Departemen

Biostatika. Pengolahan dan Analisis Data-1 Menggunakan SPSS. Fakultas Kesehatan Masyarakat Universitas Indonesia. 2010 [diunduh 23 Desember 2014]. Available From: https://ml.scribd.com/doc/157567740/ Modul-Belajar-Spss-1

7. Weksi Budiaji. Skala Pengukuran dan Jumlah Respon Skala Likert. Fakultas Pertanian Universitas Sultan Ageng Tirtayasa. $\quad 10$ September 2013 [diunduh 29 Desember 2014]. Available from : http://wbudiaji.files.wordpress.com/2 013/11/36-67-1-sm.pdf

8. Notoadmojo S. Ilmu Kesehatan Masyarakat dan Prinsip-prinsip Dasar. Jakarta: Rieka Cipta; 2005

9. Herdiyanto J. Gambaran tingkat pengetahuan dan sikap waria tentang penyakit infeksi menular seksual di Kota Pontianak tahun 2014. Fakultas Kedokteran Universitas Tanjungpura; 2014: 15 